\title{
ERYTHRINA L. (FABACEAE): UMA ABORDAGEM BIBLIOMÉTRICA
}

\section{ERYTHRINA L. (FABACEAE): A BIBLIOMETRICAL APPROACHE}

\section{Altamir Rocha Antunes}

Biólogo, Universidade do Extremo Sul Catarinense (UNESC). E-mail: altarmirmad@unesc.net

\section{Bruna Baldessar Ghislandi} Bióloga, UNESC. E-mail: bruna_bghislandi@hotmail.com

lara Zaccaron Zanoni Bióloga, UNESC. E-mail: iara_zanoni@hotmail.com

Amanda Vieira Matiola Bióloga, UNESC. E-mail: amanda.matiola1@gmail.com

Gisele Pezente

Bióloga, UNESC. E-mail: gipezentee@outlook.com

Patricia de Aguiar Amaral Professora do Programa de PósGraduação em Ciências

Ambientais (PPGCA), UNESC. Email: paa@unesc.net

Vanilde Citadini-Zanette Professora do PPGCA, UNESC.

E-mail:vcz@unesc.net

Guilherme Alves Elias

Professor Colaborador do PPGCA, UNESC. E-mail: guilherme@unesc.net

Robson dos Santos Professor do PPGCA, UNESC. E-mail: rsa@unesc.net

\section{Resumo}

As espécies de Erythrina possuem destaque na medicina popular, na recuperação ambiental, no paisagismo e outros tipos de usos. Estas informações levaram à investigação científica do gênero. Portanto, esse artigo realizou uma análise bibliométrica das espécies de Erythrina com distribuição no Brasil. A busca baseou-se no nome aceito e nos sinônimos das espécies do gênero Erythrina, com distribuição no Brasil, sendo amostrados os artigos que contêm este táxon no título, subtítulo, resumo ou nas palavras-chave. Os dados foram categorizados em classes de estudo. Observou-se que a maioria das publicações está relacionada às propriedades bioquímicas. Essa predominância vem da descoberta da produção de alcaloides pelas espécies de Erythrina. E. velutina é a espécie foco mais comum, ultrapassando a produção decorrente de E. crista-galli. A ascensão de $E$. velutina nas pesquisas mais recentes pode ser resultado da saturação da pesquisa com E. crista-galli. Em relação às demais classes de estudo, pouco se sabe sobre a biologia das espécies, reforçando a continuidade da investigação científica e preenchimento das lacunas de estudos com o gênero Erythrina.

Palavras-Chave: Papilionoideae, Cienciometria, Produção Científica.

\begin{abstract}
Erythrina L. stand out in folk medicine, environmental restoration, landscaping and other types of uses. These characteristics led to improvement the scientific research of the Erythrina genus. Therefore, this article aimed to perform a bibliometric analysis of Erythrina species distributed in Brazil. The search was based on the accepted name and synonyms of Erythrina species, with natural distribution in Brazil, being sampled the articles that contain this taxon in the title, subtitle, abstract or keywords. Data were categorized into study classes. Most publications were related to biochemical properties. This predominance comes from the discovery of alkaloid production by Erythrina species. E. velutina was the most common species, surpassing E. crista-galli scientific production. The rise of E. velutina in more recent research may be a result of the saturation of E. cristagalli research field. In relation to the other classes of study, little is known about the biology of the species, reinforcing the continuity of the scientific investigation and consequently, filling the gaps of studies with the Erythrina genus.
\end{abstract}

Keywords: Papilionoideae, Scientometry, Scientific Productivity. 


\section{INTRODUCTION}

Fabaceae Lindl. has approximately 751 genera and more than 19.000 species, being the richest botanical family in Brazil (BATISTA, 2015) and one of the most representative in the world (BRUNEAU et al., 2013). It has six subfamilies:

Cercidoideae, Detarioideae, Duparquetioideae, Dialioideae, Caesalpinioideae e Faboideae (STEVENS, 2017). Erythrina L. is one of the main genera of the subfamily Faboideae, with approximately 120 species distributed in tropical and subtropical regions of the world (DA SILVA et al., 2013), and occurs in all Brazilian biomes (DA SILVA et al., 2013) with 11 species (Flora do Brazil 2020 under construction, 2018).

Erythrina's species stand out in the use as medicinal plants, in addition to notorious use in the environmental recovery and landscaping, besides the traditional use as materials for dyeing and making musical instruments (BACKES; IRGANG, 2002). Studies on Erythrina have been carried out and published almost a century ago (DEULOFEU; HUG; MAZZOCCO, 1939) and almost all production related to the genre is being published and available in online databases.

Due to the increasing number of published papers, the production of mechanisms to organize the publications in order to quantify, control, trace and disseminate all the knowledge already produced and indexed was stimulated (ZAPPI et al., 2016). In this context, the purpose of this bibliometric study was to analyze the literature on Erythrina with natural distribution in Brazil, considering the fluctuations in scientific production within the temporal gradient, areas of knowledge and according to the different species of the genus.

\section{MATERIAL AND METHODS}

The survey of papers was conducted in the electronic databases Web of Science, Scopus and Scielo. We registered all review and original papers containing the accepted name and synonyms of species (Table 1) (FLORA DO BRASIL 2020 EM CONSTRUÇÃO, 2018).

Table 1 - Native Erythrina species from Brazil, their synonyms and popular names.

\begin{tabular}{c|c|c}
\hline Species & Synonyms & Popular names \\
\hline Erythrina amazonica Krukoff & None & mulungu \\
\hline Erythrina cristagalli L. & & corticeira \\
\cline { 3 - 3 }
\end{tabular}


Revista Tecnologia e Ambiente, v. 27, 2021, Criciúma, Santa Catarina/SC - ISSN Eletrônico 2358-9426 e ISSN Impresso 1413-8131

\begin{tabular}{|c|c|c|}
\hline Species & Synonyms & Popular names \\
\hline & $\begin{array}{l}\text { Erythrina fasciculata Benth. } \\
\text { Erythrina laurifolia Jacq. } \\
\text { Erythrina pulcherrima Tod. }\end{array}$ & \\
\hline Erythrina dominguezii Hassl. & None & ceibo rosado \\
\hline Erythrina falcata Benth. & $\begin{array}{c}\text { Erythrina crista-galli var. inermis Speg. } \\
\text { Erythrina martii Colla }\end{array}$ & bico-de-papagaio \\
\hline Erythrina fusca Lour. & $\begin{array}{c}\text { Erythrina atrosanguinea Ridl. } \\
\text { Erythrina caffra Blanco } \\
\text { Erythrina fusca var. inermis Pulle } \\
\text { Erythrina glauca Willd. } \\
\text { Erythrina moelebei Vieill. ex Guillaumin \& } \\
\text { Beauvisage } \\
\text { Erythrina ovalifolia } \text { Roxb. }\end{array}$ & suinã \\
\hline $\begin{array}{c}\text { Erythrina poeppigiana (Walp.) } \\
\text { O.F.Cook }\end{array}$ & $\begin{array}{c}\text { Erythrina amasisa Spruce } \\
\text { Erythrina darienensis Standl. } \\
\text { Erythrina micropteryx Poepp. ex Urb. } \\
\text { Erythrina pisamo Pos.-Arang. }\end{array}$ & eritrina-do-alto \\
\hline Erythrina similis Krukoff & None & mulungu \\
\hline Erythrina speciosa Andrews & $\begin{array}{c}\text { Erythrina graefferi Tineo } \\
\text { Erythrina poianthes Brot. } \\
\text { Erythrina poianthes var. subinermis Lindl. } \\
\text { Erythrina reticulata C. Presl } \\
\text { Erythrina speciosa var. rosea N.F. Mattos }\end{array}$ & $\begin{array}{l}\text { corticeira-do- } \\
\text { banhado }\end{array}$ \\
\hline Erythrina ulei Harms & Erythrina xinguensis Ducke & mulungu \\
\hline Erythrina velutina Willd. & $\begin{array}{c}\text { Erythrina aculeatissima Desf. } \\
\text { Erythrina aurantiaca } \text { Ridl. } \\
\text { Erythrina splendida Diels }\end{array}$ & eritrina \\
\hline Erythrina verna Vell. & $\begin{array}{c}\text { Erythrina flammea Herzog } \\
\text { Erythrina mulungu Mart. ex Benth. }\end{array}$ & suinã \\
\hline Erythrina mulungu Mart. & Erythrina dominguezii Hassl. & mulungu \\
\hline
\end{tabular}


Therefore, we search for the taxa in the title, abstract and keywords. All papers were classified in study classes according to the main goal of the paper [Table 2; (ELIAS et al., 2015)].

Table 2 - Study classes for paper's classification of Erythrina genus.

\begin{tabular}{l|l|l}
\hline Classes & \multicolumn{1}{|c}{ Study Classes } & \multicolumn{1}{|c}{ Description } \\
\hline $\mathrm{C} 1$ & Biochemical and nutritional properties & $\begin{array}{l}\text { Plant services used as feedstock for the } \\
\text { isolation of one or more biochemical } \\
\text { substances. }\end{array}$ \\
\hline $\mathrm{C} 2$ & Ecological & $\begin{array}{l}\text { Floristics, phytosociology, phenology, } \\
\text { conservation, population dynamics and } \\
\text { interactions. }\end{array}$ \\
\hline $\mathrm{C} 3$ & Morphology, anatomy, histology, physiology and genetics & $\begin{array}{l}\text { Morphology, anatomy, histology, plant } \\
\text { physiology. }\end{array}$ \\
\hline $\mathrm{C} 4$ & Production and use & $\begin{array}{l}\text { Production and transformation of forest } \\
\text { products, use by communities or for } \\
\text { commercialization. }\end{array}$ \\
\hline
\end{tabular}

In order to evaluate the relationship of the scientific production along the temporal gradient. These models were used for the Erythrina species (more than 25 papers) and for each study class. In order to determine the association between the study classes and the Erythrina species, we used $\chi 2$ Independence Test (AGRESTI, 1996). This test generates Pearson residue values. These values indicate a study number above (positive residue) or below (negative residues) of the mean of the genus, indicating the trends for each species, compared to the mean values of the genus Erythrina. Statistical analysis was run in the R computing environment (R CORE TEAM, 2017).

\section{RESULTS AND DISCUSSON}

We registered 339 papers published in 192 scientific journals. Among the species sought (studied), E. crista-galli, E. velutina and E. poeppigiana stood out, representing $75 \%$ of the published literature (Table 3). The scientific production on Erythrina increased along the temporal gradient, however, until the 80'decade, publications were scares. From 1938 to 1978 only nine papers were published, representing less than a third of the publications of the 1980s (29 papers). From 2000's, the increase was representative (Fig. 1). 
Figure 1 - Overview of the scientific production on Native Erythrina species from Brazil.

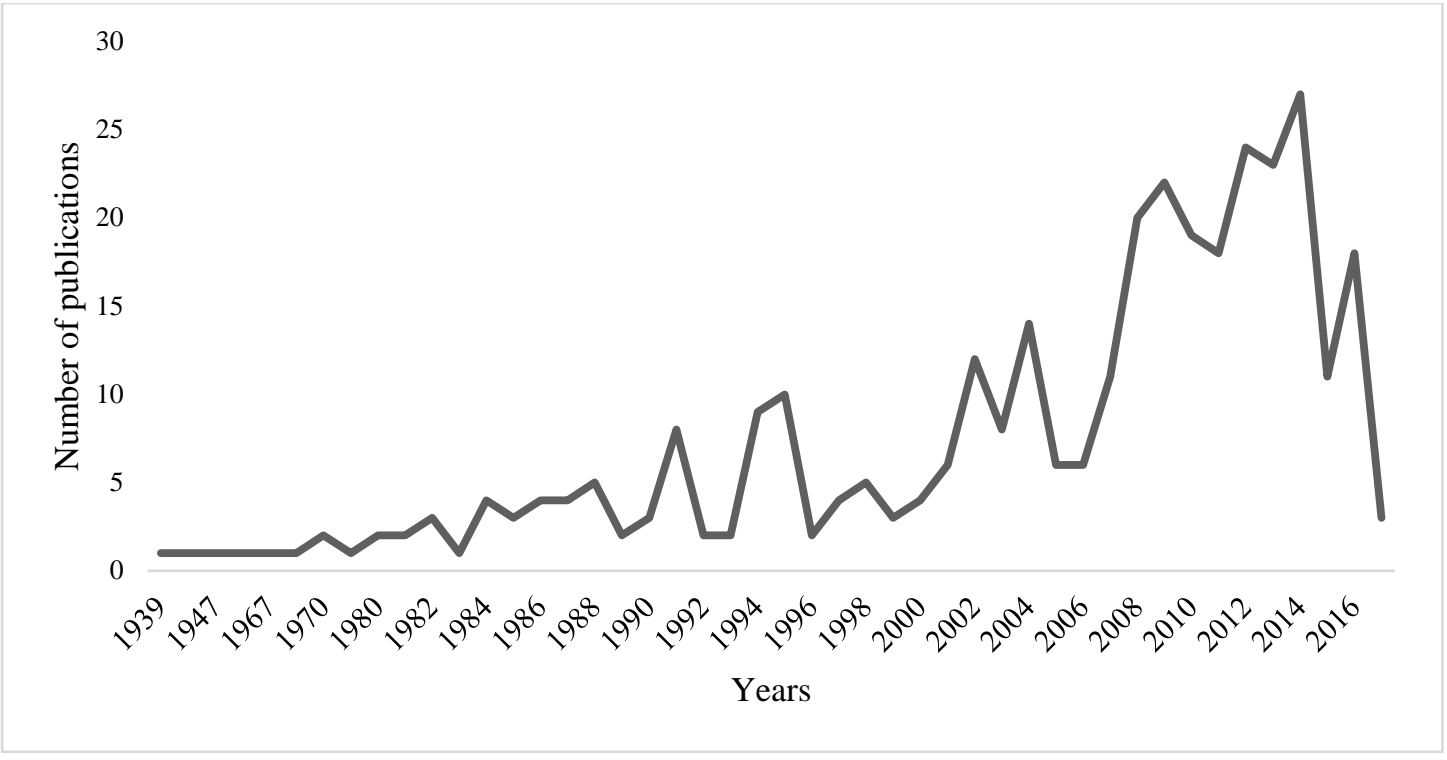

Although Erythrina species are known for the great diversity and concentration of chemical compounds, there are few studies evaluating the potential of the genus (VIVOT et al., 2012). We did not register publications on Erythrina amazonica, Erythrina similis and Erythrina ulei, although their occurrences are registered for at least three Brazilian states (MARTINS; TOZZI, 2018).

Most of the publications are related to the biochemical and nutritional properties of the species (C1). The study class $\mathrm{C} 1$ (Table 3 ) concentrated about $65 \%$ of all scientific production. This predominance is derived from the discovery of large alkaloid production by Erythrina species (FOLKERS; UNNA, 1938; KUNTIYONG et al., 2017). In addition to these compounds, the genus is known for its bioavailability in flavonoids, metabolites that can act as antifungal, antibacterial, among others (YENESEW et al., 2005).

Besides that, the ecological class also stood out with $21.3 \%$ of the published papers. Many of them were focused on the association of Erythrina species in agroforestry systems (ZAHAWI et al., 2015), their use in ecological restoration (ZAHAWI; HOLL, 2009) or the association of these species with the soil (ZAHAWI; HOLL, 2009). Erythrina species are commonly associated with agroforestry systems, in association mainly with coffee (Coffea arabica L.) and cocoa (Theobroma cacao L.), being beneficial for biodiversity conservation without undermining crop yields (BEER 
et al., 1990; MEYLAN et al., 2017; MUNROE et al., 2015; RUSSO, 1991).This management system can also be used to increase the provision of ecosystem services, such as regulation of pests and diseases; maintenance of soil fertility; provisioning of agroforestry products and carbon sequestration (CERDA et al., 2017). Our results indicated that scientific production, within each class, varied significantly between species (Table 3 ).

Table 3 - Number of published papers on Erythrina species and study classes, C1: Biochemical and nutritional properties; C2: Ecological; C3: Morphology, anatomy, histology, physiology and genetics; C4: Production and use.

\begin{tabular}{llllll}
\hline Species & Total & C1 & C2 & C3 & C4 \\
\hline Erythrina amazonica Krukoff & 0 & 0 & 0 & 0 & 0 \\
Erythrina crista-galli L. & 122 & 111 & 6 & 3 & 2 \\
Erythrina dominguezii Hassl. & 2 & 0 & 2 & 0 & 0 \\
Erythrina falcata Benth. & 14 & 7 & 5 & 1 & 1 \\
Erythrina fusca Lour. & 22 & 11 & 11 & 0 & 0 \\
Erythrina poeppigiana (Walp.) O.F.Cook & 56 & 18 & 27 & 4 & 7 \\
Erythrina similis Krukoff & 0 & 0 & 0 & 0 & 0 \\
Erythrina speciosa Andrews & 17 & 10 & 1 & 6 & 0 \\
Erythrina ulei Harms & 0 & 0 & 0 & 0 & 0 \\
Erythrina velutina Willd. & 72 & 35 & 19 & 13 & 5 \\
Erythrina verna Vell. & 34 & 28 & 4 & 2 & 0 \\
\hline Total & $\mathbf{3 3 9}$ & $\mathbf{2 2 0}$ & $\mathbf{7 5}$ & $\mathbf{2 9}$ & $\mathbf{1 5}$ \\
\hline
\end{tabular}

* Species evaluated by the Pearson $\chi 2$ test. Red / blue - categories with residue values $\geq$ of \pm 2 .

Erythrina crista-galli presented the highest number of published papers, corresponding to more than $90 \%$ of the papers registered. It is used in antibacterial and antioxidant action (TJAHJANDARIE et al., 2014; VIVOT et al., 2012). In addition, it has an important ecological role in pollination in cultivated and natural forests (COSTA; MORAIS, 2008; GALETTO et al., 2000), with a diversity of pollinators, highlighting Apis mellifera and Xylocopa sp. and four species of hummingbird: Chlorostilbon aureoventris (Shaw, 1812), Hylocharis chrysura (Shaw, 1812), Heliomaster furcifer (Shaw, 1812) and Leucochloris albicollis (Vieillot, 1818) (COSTA; MORAIS, 2008).

On the other hand, E. poeppigiana presents the highest values of the Pearson residues in the class $\mathrm{C} 2$ and $\mathrm{C} 4$ (commercial uses), against the general overview of the 
scientific production whose majority is in the area of biochemistry $(\mathrm{C} 1)$. The different approach that the research gives to this species is due to its use in agroforestry systems associated with coffee and cocoa (ZAHAWI; HOLL, 2009).

The first paper to treat E. velutina was Barros et al. (1970) that studied the effect of ethanolic and aqueous extracts of this plant, along with 44 other native species. In the following decades, there was a predominance of studies classified in study class $\mathrm{C} 1$. Even so, E. velutina stands out due to the high scientific production in classes $\mathrm{C} 2$ and C3 (positive residues). This species is the most used in agroforestry systems (ZAHAWI; HOLL, 2009), which justifies the interest of the studies that aim to know the structure and ecology of the species. Considering the growing demand for economic development, associated with sustainable techniques, agroecosystems have been increasingly studied in terms of productivity and environmental impact (HASSAN; HADDAWY; ZHU, 2014), where the ecological interactions of the species composing the agroforestry.

On the island of Fernando de Noronha, E. velutina is visited by birds (SAZIMA et al., 2009), the species blooms for two days and its stigmas remain receptive to a small assembly of vertebrates, such as Zenaida auriculata noronha (Des Murs, 1847), Vireo gracilirostris (Sharpe, 1890), Elaenia ridleyana (Sharpe, 1888) and Euprepis atlanticus (currently under the accepted name of Trachylepis atlantica) (SCHMIDT, 1945) (SAZIMA et al., 2009). None of the animals cited by the authors are dependent on nectar as the main source of food, but E. velutina is the only species visited by these vertebrates (SAZIMA et al., 2009).

The oldest paper found in our study dates from 1939 and describes new alkaloids isolated from E. glauca, currently under the accepted name of E. fusca (DEULOFEU; HUG; MAZZOCCO, 1939).. This study was not found in our research because it was within the category of Discussion, our search limited papers in the category "Original Papers" and "Review".

Interest in the genus Erythrina started, mainly, from 1930, when alkaloids were discovered that induced similar effects to curare, and could be used in medicine (FARIA et al., 2007). Curare was used as an adjunct to general anesthesia in order to determine abdominal muscle relaxation and some degree of bowel contraction (LIMONGI, 1946). 
The first studies on Erythrina were almost exclusively with E. crista-galli. Considering that until the 1980s, only nine articles were published, five of them corresponded to E. crista-galli, or $55.6 \%$ of the total publication. This predominance continued in the following decades, where of the 30 articles published in the 1980's, 21 were related to E. crista-galli. In the most recent studies E. velutina became the most common focus species, surpassing E. crista-galli production. This highlighted production on E. velutina, in more recent research, may be a result of the saturation on E. crista-galli research, where the lack of information about the composition and functionality of E. velutina compounds made it more attractive to the new studies. Another factor that may have influenced it is that, in addition to medicinal potential, $E$. velutina presents other study perspectives due to its application in agroecosystems. Erythrina amazonica, E. similis and E. ulei not appeared in our survey.

\section{CONCLUSIONS}

Erythrina crista-galli, E. poeppigiana, E. velutina and E. verna were the most representative species of our study, especially related to Biochemical and nutritional properties class. Regarding the other species, studies are scarce and restricts to some thematic, reinforcing the premise for the continuity of scientific research with Erythrina genus.

\section{REFERÊNCIAS}

AGRESTI, A. An introduction to categorical data analysis. 2. ed. New Jersey: John Wiley \& Sons, 1996.

ANJOS, P. et al. Análise Cienciométrica de Produções Científicas Sobre Serapilheira no Brasil. Agroforestry, v. 11, p. 223-236, 2016.

BACKES, P.; IRGANG, B. Árvores do Sul; guia de identificação \& interesse ecológico - as principais espécies nativas sul-brasileiras. $1^{\mathrm{a}}$ ed. Santa Cruz do Sul: Clube da Árvore/Instituto Souza Cruz, 2002.

BEER, J. et al. Modelling agroforestry systems of cacao (Theobroma cacao) with laurel (Cordia alliodora) or poro (Erythrina poeppigiana) in Costa Rica. Agroforestry Systems, v. 12, n. 3, p. 229-249, dez. 1990.

BFG. Growing knowledge: an overview of Seed Plant diversity in Brazil. Rodriguésia, v. 66, n. 4, p. 1085-1113, 2015.

BRUNEAU, A. et al. Legume phylogeny and classification in the 21st century: Progress, prospects and lessons for other species-rich clades. Tiina Särkinen TAXON, 
v. 6281921, n. 622, p. 217-248, 2013.

CERDA, R. et al. Effects of shade, altitude and management on multiple ecosystem services in coffee agroecosystems. European Journal of Agronomy, v. 82, p. 308319, jan. 2017.

COSTA, R. A. C. V.; MORAIS, A. B. B. DE. Fenologia e visitantes florais de Erythrina crista-galli L. (Leguminosae: Faboideae) em Santa Maria, Rio Grande do Sul, Brasil. Biotemas, v. 21, n. 2, p. 51-56, 30 set. 2008.

DA SILVA, M. M. B. et al. Anatomy of leaf and stem of Erythrina velutina. Revista Brasileira de Farmacognosia, v. 23, n. 2, p. 200-206, 1 mar. 2013.

DEULOFEU, V.; HUG, E.; MAZZOCCO, P. 377. Studies on Argentine plants. Part I. Hypaphorine from Erythrina cristagalli. Journal of the Chemical Society (Resumed), v. 0, n. 0, p. 1841, 1 jan. 1939.

ELIAS, G. A. et al. Arecaceae: Análise bibliométrica das espécies nativas do estado de Santa Catarina. Ciência e Natura, v. 37, n. 1, p. 85-92, 20 jan. 2015.

FARIA, T. DE J. et al. Alcalóides de flores e folhas de Erythrina speciosa Andrews. Química Nova, v. 30, n. 3, p. 525-527, jun. 2007.

FOLKERS, K.; UNNA, K. Erythrina Alkaloids. II. A Review, and new Data on the Alkaloids of Species of the Genus Erythrina. The Journal of the American Pharmaceutical Association, v. 27, n. 8, p. 693-699, ago. 1938.

GALETTO, L. et al. Reproductive biology of Erythrina crista-galli (Fabaceae). Annals of the Missouri Botanical Garden, v. 87, n. 2, p. 127-145, 2000.

HASSAN, S.-U.; HADDAWY, P.; ZHU, J. A bibliometric study of the world's research activity in sustainable development and its sub-areas using scientific literature. Scientometrics, v. 99, n. 2, p. 549-579, maio 2014.

KUNTIYONG, P. et al. Synthesis of a tetracyclic core of Erythrina alkaloids and analogs of crispine A. Tetrahedron, v. 73, n. 30, p. 4426-4432, 27 jul. 2017.

LIMONGI, J. P. O uso do curare como auxiliar da anestesia. Scientific basis of the homeopathic healing principle in modern pharmacology., v. 30, n. 151, p. 359-364, 6 jul. 1946.

MEYLAN, L. et al. Evaluating the effect of shade trees on provision of ecosystem services in intensively managed coffee plantations. Agriculture, Ecosystems \& Environment, v. 245, p. 32-42, jul. 2017.

MUNROE, J. W. et al. Soil microbial and nutrient properties in the rhizosphere of coffee under agroforestry management. Applied Soil Ecology, v. 93, p. 40-46, set. 2015.

R CORE TEAM. R: A Language and Environment for Statistical Computing. Vienna: R Foundation for Statistical Computing, 2017.

RUSSO, R. O. Erythrina (Leguminosae: Papilionoideae): A versatile genus for agroforestry systems in the tropics. Journal of Sustainable Agriculture, v. 1, n. 2, p. 89-109, jan. 1991.

SAZIMA, I.; SAZIMA, C.; SAZIMA, M. A catch-all leguminous tree: Erythrina 
velutina visited and pollinated by vertebrates at an oceanic island. Australian Journal of Botany, v. 57, n. 1, p. 26, 2009.

STEVENS, P. F. Angiosperm Phylogeny IV. Disponível em: <http://www.mobot.org/MOBOT/research/APweb>.

TJAHJANDARIE, T. S. et al. Antimalarial and antioxidant activity of phenolic compounds isolated from Erythrina crista-galli L. Journal of Chemical and Pharmaceutical Research, v. 6, n. 4, p. 786-790, 2014.

VIVOT, E. P. et al. Antibacterial activity of medicinal plants in the flora of Entre Ríos (Argentina). Ciencias Exactas y naturales, v. 45, p. 165-185, 2012.

YENESEW, A. et al. Antimicrobial flavonoids from the stem bark of Erythrina burttii. Fitoterapia, v. 76, n. 5, p. 469-472, jul. 2005.

ZAHAWI, R. A. et al. Using lightweight unmanned aerial vehicles to monitor tropical forest recovery. Biological Conservation, v. 186, p. 287-295, 2015.

ZAHAWI, R. A.; HOLL, K. D. Comparing the performance of tree stakes and seedlings to restore abandoned tropical pastures. Restoration Ecology, v. 17, n. 6, p. 854-864, 2009. 